\title{
Reconnaissance of Eocambrian and Lower Palaeozoic strata in south-western Peary Land, North Greenland
}

\section{Peter R. Dawes}

During the 1975 ice drilling operations of the Greenland Ice Sheet Programme (GISP) on the Hans Tavsens Iskappe, three days were spent in the area south-west of the ice cap. This allowed a brief examination of the bedrock and Quaternary features from a single camp on the east side of Adams Gletscher (fig. 4 and Weidick, this report).

The area visited is at the western end of Wandel Dal, the broad low valley linking Independence Fjord in the east with J. P. Koch Fjord. The main geological and physiographical features of the region were recorded from the air by Lauge Koch in 1938. Previous geologists to visit the area have been on the dog sledge route through Wandel Dal, e.g. J. C. Troelsen and K. Ellitsgaard-Rasmussen on Eigil Knuth's Danish Peary Land expedition 1947-51 but almost nothing has been published.

The most important results of the present visit are:

(1) The recognition at Adams Gletscher of the well-known Eocambrian - Lower Palaeozoic Jørgen Brønlund Fjord sequence and the continuation of it to the west of Peary Land.

(2) The discovery of fossiliferous Middle Cambrian strata (hitherto unknown in Peary Land) overlain by oolitic limestones in the interval between the Brønlund Fjord Formation and the Wandel Valley Formation, and

(3) The recognition of substantial post-Silurian fault movements in the platform.

\section{Regional setting and structure}

Southern Peary Land forms the eastern part of the Proterozoic - Lower Palaeozoic stable platform block that stretches across northern Greenland from the west to east coasts. The platform is characterised by shallow northward dipping strata.

In the Adams Gletscher - J. P. Koch Fjord area an Eocambrian to Silurian marine sequence at least $2500 \mathrm{~m}$ thick dips northwards at up to about $10^{\circ}$. The succession has Eocambrian-Cambrian clastic rocks and dolomite at the base overlain by thick Ordovician-Silurian carbonates. To the north the Silurian is developed as reef limestones and farther north there is a prominent facies change both laterally and vertically into clastic rocks. The uppermost part of the sequence is of dark monotonous sandstone-shale lithology (known from other parts of the North Greenland geosyncline to be of flysch facies) that may well extend into the Devonian.

Several E-W trending faults were discovered in the Adams Gletscher area. These are vertical to steeply inclined to the south. One master fault traceable from Hans Tavsens Iskappe and across Adams Gletscher shows a displacement of about $1 \mathrm{~km}$. This has reversed the normal stratigraphical outcrop pattern of the platform strata resulting in a fault block of older rocks (Eocambrian-Cambrian) outcropping to the north of the Cambrian-Ordovician sequence (fig. 4). Drag effect along the fault has produced steeply inclined beds that are well exposed on the west side of Adams Gletscher. Faults have not been studied in detail and it is 


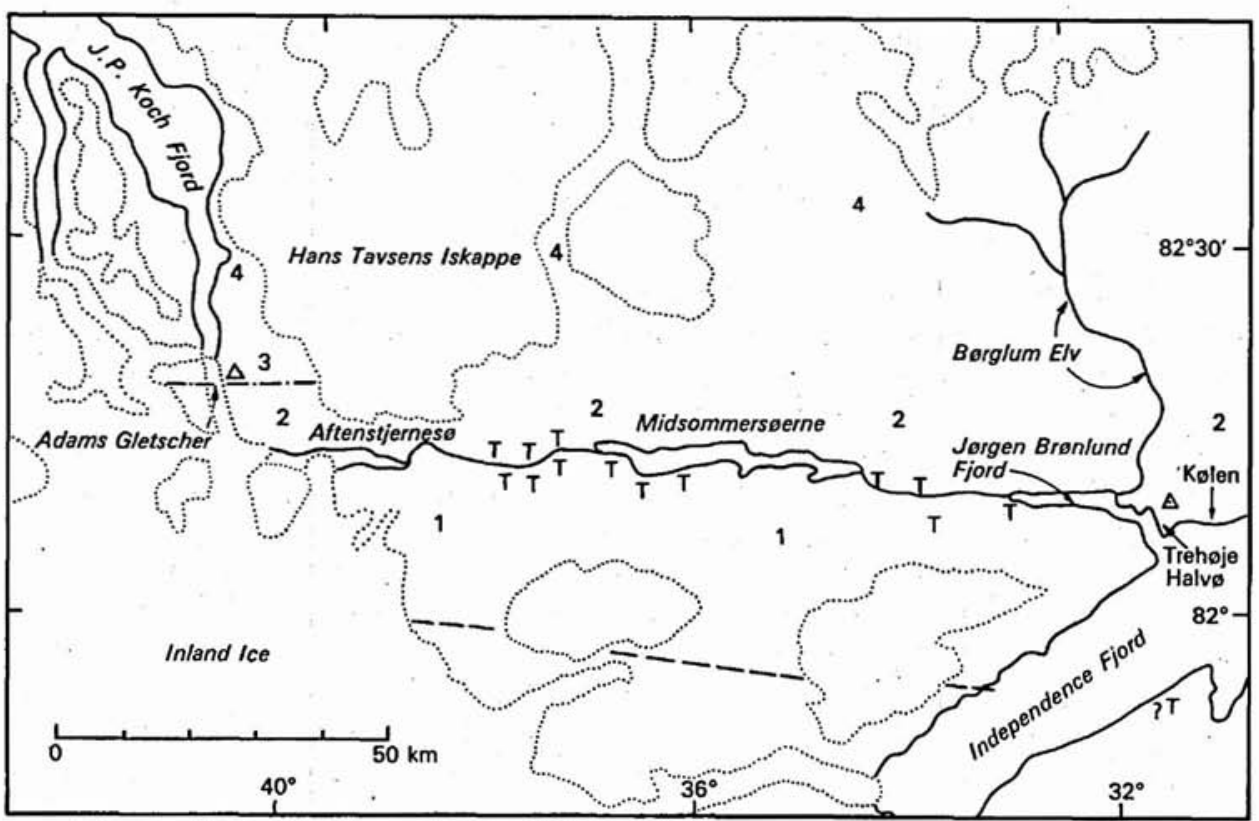

- - Southern limit of Cambrian strata, - - - - Fault, T Tillite, $\Delta$ Kap Harald Moltke Station, $\Delta$ Field camp, 1 Proterozoic, Eocambrian and Cambrian, 2 Cambro-Ordovician, 3 Eocambrian - Cambrian, 4 Ordovician-Silurian

Fig. 4. Sketch map of the Jørgen Brønlund Fjord - Midsommersøerne - Adams Gletcher region of southern Peary Land, North Greenland.

unclear whether the recorded displacement is due to downthrow and tilting of a southern block rather than a northern upheaval of the older rocks along a thrust fault.

\section{Stratigraphy}

The short time available allowed only a cursory examination of parts of two fault-separated sections in the southern and oldest part of the sequence to the east of Adams Gletscher. Correlation of strata across the fault allows the total sequence to be divided into 9 reconnaissance units. The thicknesses given are field estimates.

Unit $A$ at the base of the sequence has about $180 \mathrm{~m}$ exposed. It is composed of yellow-weathering dolomite and dolomitic breccia overlain (?disconformably) by grey, often rusty weathering sandstone and quartz pebble grit in which cross-bedding is common. This is followed by grey, fine- to medium-grained vuggy dolomite. Cross-bedding indicates a transport direction from the south and south-west.

Unit $B(c .90 \mathrm{~m})$ is a dark, thin banded, recessive unit of uncertain composition. It is characteristically scree covered but contains some yellow-weathering, fine-grained, grey dolomites.

Unit $C($ c. $15 \mathrm{~m})$ is composed of grey to pale brown sandstone and grit that has a yellow to deep rusty red weathering colour. It is resistant and characteristically forms a ledge with recessive rock above and below. 
Unit $D($ c. $290 \mathrm{~m})$ is composed of three dark recessive and mainly scree-covered sub-units separated by two lighter coloured resistant ones. The unit was not explored throughout but black, dark grey and green shales, in places fissile, siltstones and fine-grained sandstones are represented in the recessive sequence. Grey to greenish grey sandstone, in places with cross stratification, makes up at least part of the resistant sections. Banding of lighter and dark coloured rocks occurs in the middle part of the unit.

Unit $E($ c. $180 \mathrm{~m})$ is a resistant cliff-forming unit in which three sub-units are recognisable. The basal sub-unit of yellow weathering, massive looking, dolomite and dolomite breccia is overlain by a seemingly thinner bedded, banded sub-unit containing alternating grey to purplish grey and yellow weathering dolomite and an upper sub-unit of similar character to the basal sub-unit. The upper surface of the unit in places has a slightly undulating surface and may represent a disconformity.

The upper sub-unit has yielded a number of the small inarticulate brachiopods Linnarssonia and fragments of Hyolithellus (J. S. Peel, personal communication). Both these forms are present in the Lower Cambrian assemblage known from the basal bed of the Bronlund Fjord Formation suggesting a similar age for the upper sub-unit.

Unit $F(c .200 \mathrm{~m})$ is composed of thin bedded, dark grey to bluish grey dolomite and dolomite breccia at the base, light coloured rather massive dolomite and intraformational breccia in the middle part and brown-grey to purplish grey weathering, thin to medium bedded dolomite at the top.

Certain samples from near the base of the unit have yielded a small fauna containing the agnostid trilobite Peronopsis and the monophacophoran Helcionella (J. S. Peel, personal communication), indicative of a Middle Cambrian age for at least the lower part of the unit.

Unit $G(c .300 \mathrm{~m})$ is a light weathering, rather thick bedded unit of uniform appearance, composed of white oolitic limestone at the base passing up into medium-grained dolomite and limestone. Individual beds generally thin southwards and in many places inclination of bedding is much steeper than normal. The upper contact with unit $\mathrm{H}$ is evidently a major disconformity.

Unit $H($ c. $430 \mathrm{~m})$ is of varying dolomite and limestone lithology containing medium bedded light and dark, banded strata in both the lower and upper parts and with yellow weathering generally thinner bedded dolomites in the middle part. Mottling and silicification of the carbonates are common and intraformational breccias and nodules and thin chert beds occur.

A bluish grey mottled and silicified limestone sample of uncertain stratigraphical position (middle to upper part of the unit) has yielded on treatment with dilute acetic acid a Lower Ordovician (probably late Canadian) fauna (J. S. Peel, personal communication). This fauna includes: indeterminate brachiopods, the gastropods Maclurites sp., ?Peruniscus sp. and ?Ceratopea $\mathrm{sp}$., as well as several chitinozoa, seemingly Lagenochitina.

Unit I $\left(250 \mathrm{~m}^{+}\right)$for the most part is composed of uniformly bedded grey to yellow weathering dolomite and limestone showing common mottling and brecciation. The uppermost part examined south of the fault contains thin-bedded, grey to light brown, hard, fine-grained arenaceous dolomite and calcareous siltstone, that contains dark coloured chert nodules.

Strata younger than unit I forming the well-exposed sections on both sides of J. P. Koch Fjord farther to the north were not visited in the field. 
Basic dykes

Several NNW-trending brown weathering basic dykes cut the platform sequence in the Adams Gletscher - J. P. Koch Fjord region. One 5 to $12 \mathrm{~m}$ wide dyke examined on the east side of Adams Gletscher varies from a homogenous to porphyritic and vesicular basic rock which in places contains xenoliths.

The dykes are almost certainly the western extension of the dolerite swarm recorded in the Midsommersøerne area (Jepsen, 1971) for which a Cretaceous age has been suggested. Dykes of similar trend were noted from the air to the west of Adams Gletscher and in Freuchen Land.

\section{Correlation}

The classical Eocambrian-Lower Palaeozoic sequence of the Jørgen Brønlund Fjord region (Troelsen, 1949, 1956; Jepsen, 1971; Peel \& Christie, 1975) can be traced westwards throughout Peary Land. Troelsen (1956 and personal communication) after erecting formational names for the sequence in the Jørgen Brønlund Fjord region (1949) was able later to trace several of the formations westwards and into the Adams Gletscher area. The prominent cliff-forming Bronlund Fjord Formation forms frequent outcrops on the north side of Wandel Dal everywhere overlying the dark recessive Buen Formation. It forms the base of the section (unit E) on both sides of Adams Gletscher at its head and can be traced further westward into Freuchen Land at the head of Nordenskjöld Fjord. Using this formation as a marker the following tentative correlation with the Jørgen Brønlund Fjord sequence is suggested (Table 1).

Late Precambrian igneous intrusions are an ubiquitous part of the Inuiteq S $\varnothing$ Formation in southern Peary Land. The absence of such intrusions in basal strata of the Adams Gletscher sequence strongly suggests (although does not prove) that the entire succession there post-dates the regional unconformity marking the top of the Inuiteq Sø Formation. However, no glacial deposits equivalent in age to the tillite of the overlying Morænes $\varnothing$ Formation were encountered in the Adams Gletscher sequence. Exposures of deep red weathering tillite can be traced from Jørgen Brønlund Fjord into the Midsommersøerne area (Troelsen, 1956) and were noted from the air on both sides of Wandel Dal over $15 \mathrm{~km}$ west of $\emptyset v$ vre Midsommersø (fig. 4).

Units A, B and C are in stratigraphical positions to be correlated with the Morænes $\varnothing$ and Portfjeld Formations of Jepsen (1971). Certain differences prevent more detailed correlation but it is worth mentioning that the conspicuous ledge-forming rusty unit $\mathrm{C}$ recognised over large parts of southern Peary Land, most probably corresponds to rusty beds described by Jepsen (1971) near the top of the Portfjeld Formation.

A significant discovery is the presence of Middle Cambrian strata (unit F) overlain by oolitic limestones of uncertain age (unit G) in the Adams Gletscher section. Middle Cambrian strata have not hitherto been recorded in Peary Land although it has been inferred elsewhere (Dawes, 1976) that the middle to upper parts of the Brønlund Fjord Formation could contain strata of post-Lower Cambrian age. This reflection was based on the fact that the hitherto only known fauna from the formation originates from the basal beds (Troelsen, 1956; Peel et al., 1974; Peel \& Christie, 1975). In any case, the Brønlund Fjord Formation in 
Table 1. Comparison of Proterozoic, Eocambrian and Lower Palaeozoic sequences in south-eastern and south-western Peary Land, North Greenland

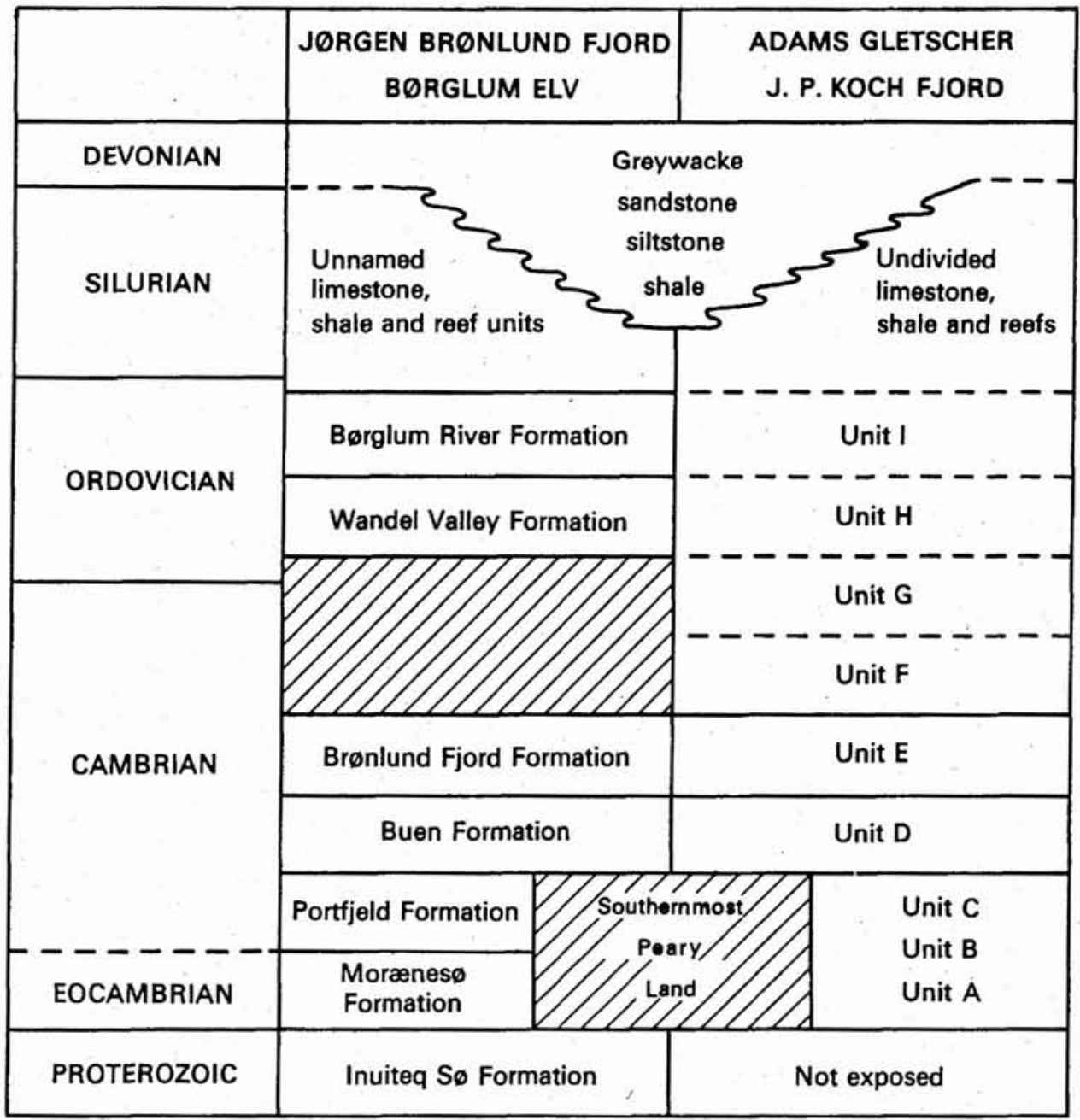

Jørgen Brønlund Fjord is overlain by the Wandel Valley Formation, the basal beds of which are dated as late Lower Ordovician (late Canadian) by the gastroped Ceratopea (Yochelson \& Peel, 1975).

It is thus of some interest to record the occurrence of Linnarssonia and Hyolithellus in the upper part of the formation at Adams Gletscher, especially since both these forms appear in the late Lower Cambrian assemblage known from the basal part of the formation farther to the east. This evidence, as well as the presence of Middle Cambrian strata stratigraphically above, suggests that much or the entire thickness of the Brønlund Fjord Formation is of Lower Cambrian age. 
The disconformity separating units $\mathrm{G}$ and $\mathrm{H}$ in the Adams Gletscher sequence is evidently expressed in eastern Peary Land by a less complete Cambrian section. Unit $\mathrm{H}$ in part or wholly, can be correlated with the Wandel Valley Formation both on lithological grounds and from its Canadian fauna, particularly the presence of Ceratopea. The age of unit $\mathrm{G}$ is uncertain but in view of the dating of units stratigraphically above and below, there is a possibility that a substantial thickness of strata belonging to the interval Lower Cambrian late Canadian is present in the sequence in south-western Peary Land.

The Adams Gletscher area is on the eastern side of the Victoria Fjord arch, a structural high that has been considered to have been a positive feature since late Precambrian time and to have had a marked effect on Proterozoic and later sedimentation (Dawes \& Soper, 1973). The Proterozoic Inuiteq S $\varnothing$ Formation in southern Peary Land reaches a thickness of about $900 \mathrm{~m}$; Proterozoic rocks over the Victoria Fjord area arch, if present are relatively thin,' perhaps less than $200 \mathrm{~m}$. However, while some Palaeozoic strata also show. a regional westward thinning across Peary Land towards the arch, for example the Buen Formation, it is now apparent that the Cambrian section is thicker in western than in eastern Peary Land.

Detailed field investigations in the Peary Land - Wulff Land region are needed to determine more accurately the tectonic history of the Victoria Fjord arch; a history that is much more complex than hitherto thought.

\section{References}

Dawes, P. R. 1976: Precambrian to Tertiary of northern Greenland. In Escher, A. \& Watt, W. S. (edit.) Geology of Greenland, 248-303. Copenhagen: Geol. Surv. Greenland.

Dawes, P. R. \& Soper, N.J. 1973: Pre-Quaternary history of North Greenland. Mem. Amer. Assoc. Petrol. Geol. 19, 117-134.

Jepsen, H. F. 1971: The Precambrian, Eocambrian and early Palaeozoic stratigraphy of the Jørgen Brønlund Fjord area, Peary Land, North Greenland. Bull. Grønlands geol. Unders. 96 (also Meddr Grønland 192,2), 42 pp.

Troelsen, J. C. 1949: Contributions to the geology of the area round Jørgen Brønlunds Fjord, Peary Land, North Greenland. Meddr Grønland 149,2, 29 pp.

Troelsen, J. C. 1956: The Cambrian of North Greenland and Ellesmere Island. 20 Congr. geol. int. Mexico 3 (1), 71-90.

Peel, J. S. \& Christie, R. L. 1975: Lower Palaeozoic stratigraphy of southern Peary Land, eastern North Greenland. Rapp. Grønlands geol. Unders. 75, 21-25.

Peel, J. S., Dawes, P. R. \& Troelsen, J. C. 1974: Notes on some Lower Palaeozoic to Tertiary faunas from eastern North Greenland. Rapp. Grønlands geol. Unders. 65, 18-23.

Yochelson, E. L. \& Peel, J. S. 1975: Ceratopea and the correlation of the Wandel Valley Formation, eastern North Greenland. Rapp. Grønlands geol. Unders. 75, 28-31. 